\title{
Biomedical potential of silver nanoparticles synthesized from calli cells of Citrullus colocynthis (L.) Schrad
}

\author{
Satyavani K, Gurudeeban S, Ramanathan $\mathrm{T}^{*}$ and Balasubramanian T
}

\begin{abstract}
Background: An increasingly common application is the use of silver nanoparticles for antimicrobial coatings, wound dressings, and biomedical devices. In this present investigation, we report, biomedical potential of silver nanopaticles synthesized from calli extract of Citrullus colocynthis on Human epidermoid larynx carcinoma (HEp -2) cell line.

Methods: The callus extract react with silver nitrate solution confirmed silver nanoparticles synthesis through the steady change of greenish colour to reddish brown and characterized by using FT-IR, AFM. Toxicity on HEp 2 cell line assessed using MTT assay, caspase -3 assay, Lactate dehydrogenase leakage assay and DNA fragmentation assay.

Results: The synthesized silver nanoparticles were generally found to be spherical in shape with size $31 \mathrm{~nm}$ by AFM. The molar concentration of the silver nanoparticles solution in our present study is $1100 \mathrm{nM} / 10 \mathrm{~mL}$. The results exhibit that silver nanoparticles mediate a dose-dependent toxicity for the cell tested, and the silver nanoparticles at $500 \mathrm{nM}$ decreased the viability of HEp 2 cells to 50\% of the initial level. LDH activities found to be significantly elevated after $48 \mathrm{~h}$ of exposure in the medium containing silver nanoparticles when compared to the control and Caspase 3 activation suggested that silver nanoparticles caused cell death through apoptosis, which was further supported by cellular DNA fragmentation, showed that the silver nanoparticles treated HEp2 cells exhibited extensive double strand breaks, thereby yielding a ladder appearance (Lane 2), while the DNA of control HEp2 cells supplemented with 10\% serum exhibited minimum breakage (Lane 1). This study revealed completely would eliminate the use of expensive drug for cancer treatment.
\end{abstract}

Keywords: bitter cucumber, callus extract, cell viability, HEp 2 cells

\section{Background}

Citrullus colocynthis (Bitter cucumber) belongs to the family of cucurbitaceae, which are abundantly grown along the arid soils of Southeast coast of Tamil Nadu. It has a large, fleshy perennial root, which sends out slender, tough, angular, scabrid vine-like stems. The therapeutic potentials viz., antimicrobial [1], anti inflammatory [2], anti diabetic [3] and anti oxidant [4] effect of Citrullus colocynthis have reported in our laboratory. For conservation of this potent medicinal

\footnotetext{
* Correspondence: ramanathanscholars@gmail.com Centre of Advanced Study in Marine Biology, Faculty of Marine Sciences, Annamalai University, Parangipettai 608502, India
}

plant we have micro propagated and transplanted to the coastal region of Parangipettai.

Nanoparticles usually referred as particles with a size up to $100 \mathrm{~nm}$. Nanoparticles exhibit completely new properties based on specific characteristics such as size, distribution and morphology. As specific surface area of nanoparticles is increased, their biological effectiveness can increase in surface energy [5]. Silver has long been recognized as having an inhibitory effect towards many bacterial strains and micro organisms commonly present in medical and industrial processes [6]. The most widely used and known applications of silver and silver nanoparticles are include topical ointments and creams containing silver to prevent infection of burns and open
C Biomed Central

(C) $2011 \mathrm{~K}$ et al; licensee BioMed Central Ltd. This is an Open Access article distributed under the terms of the Creative Commons Attribution License (http://creativecommons.org/licenses/by/2.0), which permits unrestricted use, distribution, and reproduction in any medium, provided the original work is properly cited. 
wounds [7]. Production of nanoparticles can be achieved through different methods. Chemical approaches are the most popular methods for the production of nanoparticles. However, some chemical methods cannot avoid the use of toxic chemicals in the synthesis protocol. Biological methods of nanoparticles synthesis using micro organisms [8], enzyme [9], and plant or plant extract have been suggested as possible ecofriendly alternatives to chemical and physical methods. Using plant for nanoparticles can be advantageous over other biological processes by eliminating the elaborate process of maintaining cell culture [10]. If biological synthesis of nanoparticles can compete with chemical methods, there is a need to achieve faster synthesis rates. The exact mechanism of silver nanoparticles synthesis by plant extracts is not yet fully understood. Only participation of phenolics, proteins and reducing agents in their synthesis has been speculated. Recently nanoencapsulated therapeutic agents such as antineoplastic drugs had been used to selectively targeting anti tumor agents and obtaining higher drug concentration at the tumour site [11]. Nanotechnology could be very helpful in regenerating the injured nerves. For biological and clinical applications, the ability to control and manipulate the accumulation of nanoparticles for an extended period of time inside a cell can lead to improvements in diagnostic sensitivity and therapeutic efficiency. This when revealed completely would eliminate the use of expensive drugs for cancer treatment [12]. The callus and leaf extract of Citrullus colocynthis reported moderate antimicrobial activity against biofilm forming bacteria [13] and harmful human pathogens [14]. Therefore the present study, we evaluated, biomedical potential of silver nanopaticles synthesized from calli extract of Citrullus colocynthis on Human epidermoid larynx carcinoma (HEp -2) cell line.

\section{Results and Discussion}

The cumulative work on plant tissue culture revealed the maximum number of calli induction was achieved from stem explants of $C$. colocynthis on MS medium enriched with $0.5 \mathrm{mg} \mathrm{L-1}$ IAA, 2, 4-D and $1 \mathrm{ppm}$ of 6BA which yielded morphogenic compact hard greenish white calli at a frequency of $80 \%$. The appearance of brown colour in the reaction mixture indicates the synthesis of silver nanoparticles form stem derived callus extract with $1 \mathrm{mM}$ silver nitrate solution (Figure 1). Our findings showed resemblance to the results already reported by in the case of callus extract of Carcia papaya [15], leaf extract of Capsicum annum [16] and in case of extract of Aloe Vera [17]. The shape of the SNP synthesized by stem derived callus extract was spherical and was found to be in the range $31 \mathrm{~nm}$ by AFM (Figure 2).

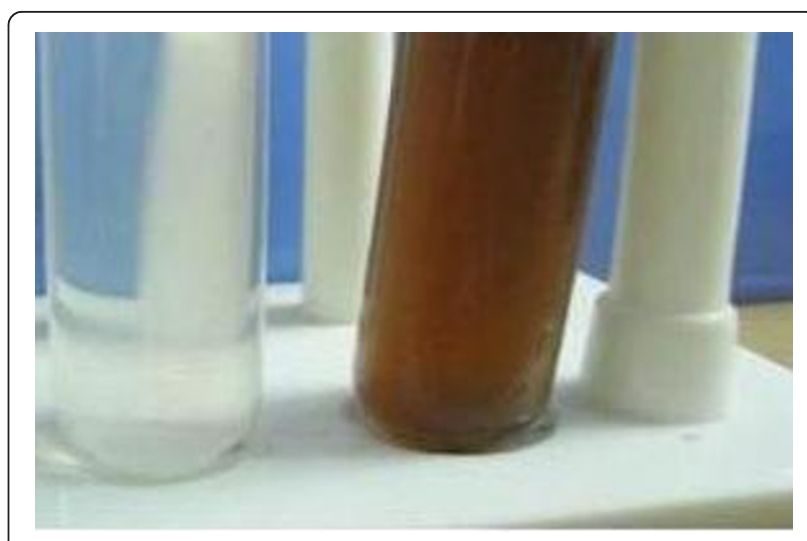

Figure $11 \mathrm{mM}$ silver nitrate solution without callus extract and silver nanoparticles with reddish brown colour. $1 \mathrm{mM}$ silver nitrate solution without callus can be seen in A and silver nanoparticles with reddish brown colour can be seen in B.

Number of absorption spectrum of the nanoparticles obtained in the present study as shown in (Figure 3 ). Among them, the absorption peak at $1020 \mathrm{~cm}^{-1}$ can be assigned a absorption peaks of $\mathrm{C}-\mathrm{O}-\mathrm{C}$ - or $-\mathrm{C}-\mathrm{O}-$, also the peak at $1020-1091 \mathrm{~cm}^{-1}$ corresponds to $\mathrm{C}-\mathrm{N}$ stretching vibrations of aliphatic amines or to alcohols or phenols representing the presence of polyphenols [18]. The absorbance peak at 1265 and $1384-1460 \mathrm{~cm}^{-1}$ correspond to the amide III and II group respectively. The peak at 1624 $\mathrm{cm}^{-1}$ is associated with stretch vibration of $-\mathrm{C}=\mathrm{C}$-and is assigned to the amide 1 bonds of proteins. The absorption at about $1384 \mathrm{~cm}^{-1}$ is notably enhanced indicating residual amount of $\mathrm{NO}_{3}$ in the solution [19]. The peak at $1539 \mathrm{~cm}^{-}$ ${ }^{1}$ may be assigned to symmetric stretching vibrations of -COO- (carboxyl ate ion) groups of amino acid residues with free carboxyl ate groups in the protein [20]. The peak at $3427 \mathrm{~cm}^{-1}$ indicates polyphenolic $\mathrm{OH}$ group along with the peak of $882 \mathrm{~cm}^{-1}$ which represents the aromatic ring $\mathrm{C}-\mathrm{H}$ vibrations, indicate the involvement of free catechin [21]. This suggests the attachment of some polyphenolic components on to silver nanoparticles. This means the polyphenols attached to silver nano particles may have atleast one aromatic ring. The peaks at $1000-1200 \mathrm{~cm}^{-1}$ indicate $\mathrm{C}-\mathrm{O}$ single bond and peaks at $1620-1636 \mathrm{~cm}^{-1}$ represent carbonyl groups $(\mathrm{C}=\mathrm{O})$ from polyphenols such as catechin gallate, epicatechin gallate and theaflavin [22] Result suggests that molecules attached with silver nanoparticles have free and bound amide group. These amide groups may also be in the aromatic rings. This concludes that the compounds attached with silver nanoparticles could be polyphenols with aromatic ring and bound amide region. In our results showed that the average number of atoms per nanoparticles are $\mathrm{N}=914047.97$. The molar concentration of the silver nanoparticles solution in our present study is $1100 \mathrm{nM} / 10 \mathrm{~mL}$. 

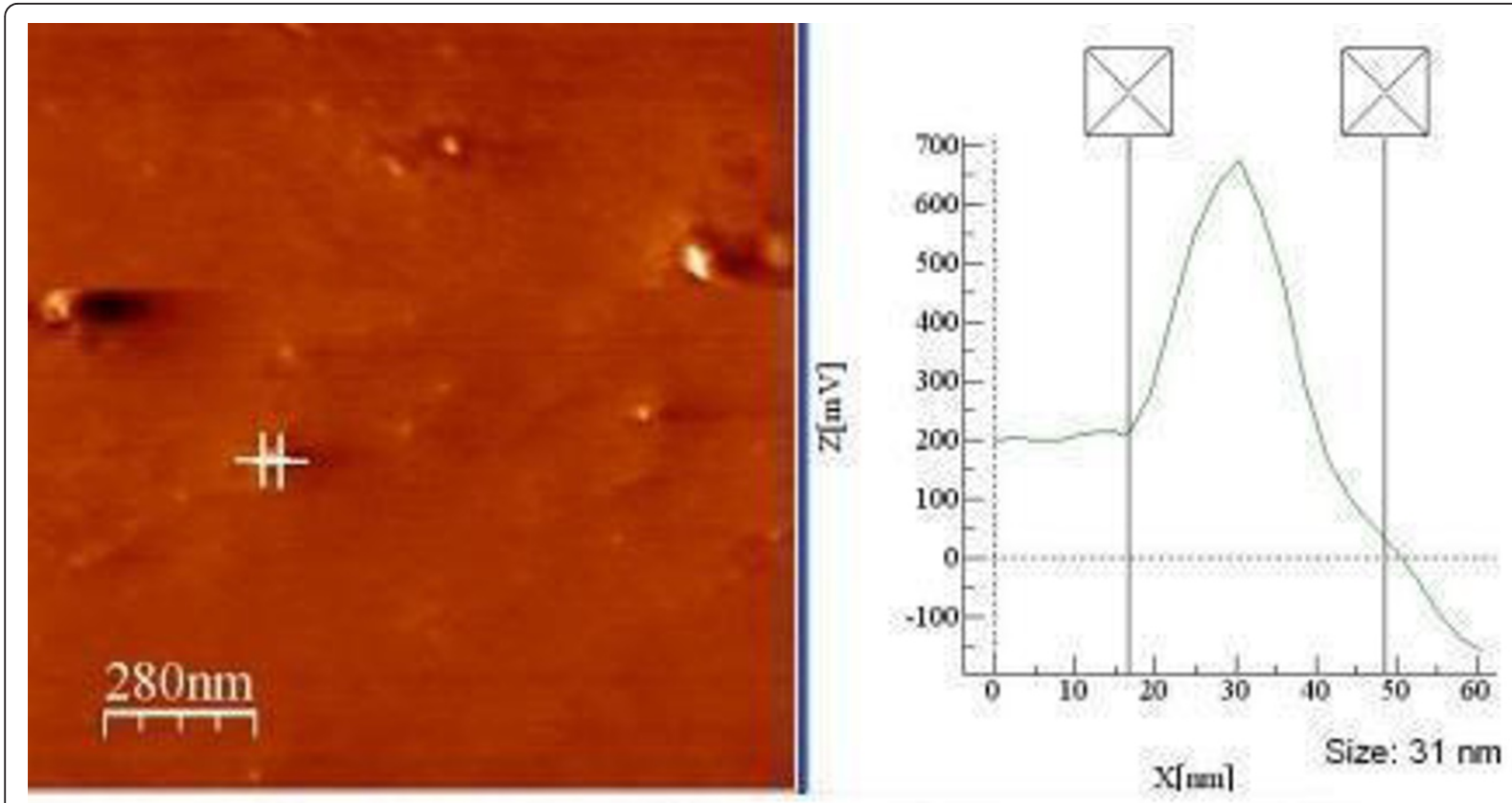

Figure 2 AFM. Tapping mode AFM (VEeco diNanoscope 3D AFM) image showed spherical shaped silver nanoparticles with size range $31 \mathrm{~nm}$.

\section{Toxicity study}

The nanoparticles synthesized using the plant system have applications in the field of medicines, cancer treatment, drug delivery, commercial appliances and sensors. The in vitro cytotoxicity effects of silver nanoparticles were screened against cancer cell lines and viability of tumor cells was confirmed using MTT assay. The silver nanoparticles were able to reduce viability of the HEp -2 cells in a dose-dependent manner as shown in (Figure 4 $\& 5)$. After five hours of treatment, the silver

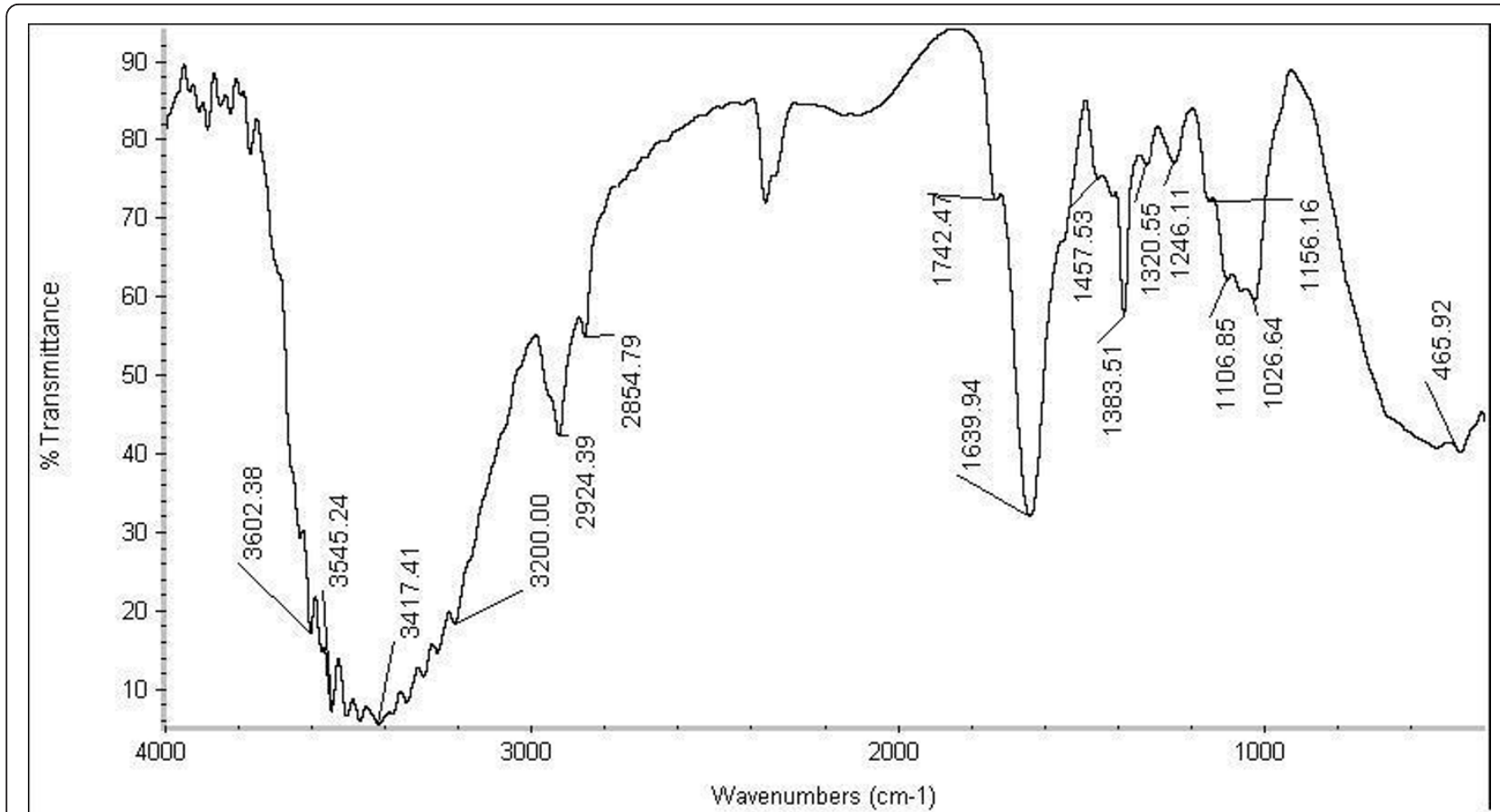

Figure 3 FT-IR. FT-IR images identified silver nanoparticles associated biomolecules. It represents compounds attached with silver nanoparticles could be polyphenols with aromatic ring and bound amide region in the peaks ranging from $1000-4000 \mathrm{~cm}^{-1}$. 

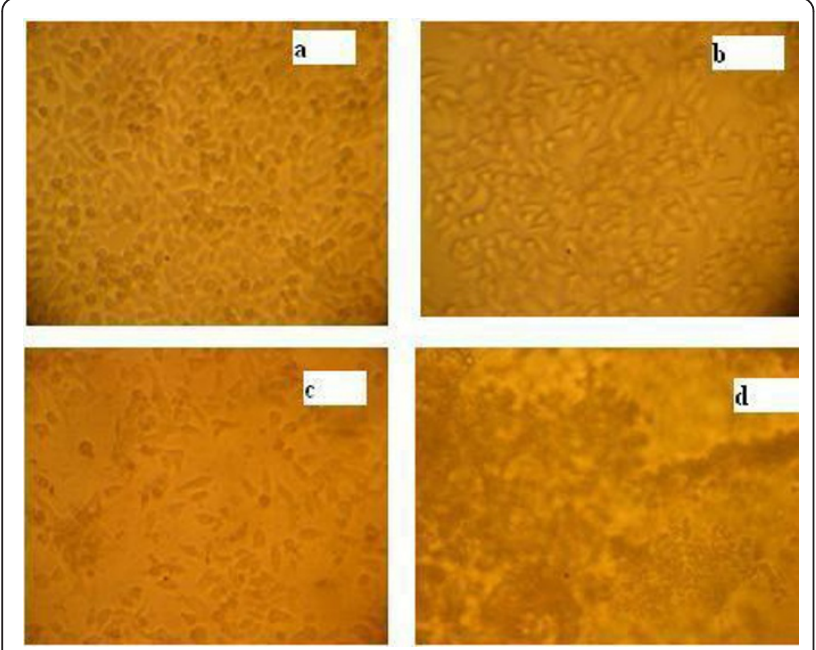

Figure 4 Dose dependent Cytotoxicity assay. Dose dependent cytotoxicity effect of SNp over cell viability (a) Normal Hep-2 cells (b) Low toxicity $15.5 \mu \mathrm{g} / \mathrm{ml}$ (c) Minimum toxicity $500 \mu \mathrm{g} / \mathrm{ml}$ (d) high toxicity $1000 \mu \mathrm{g} / \mathrm{ml}$.

nanoparticles at concentration of $500 \mathrm{nM}$ decreased the viability of HEp 2 cells to $50 \%$ of the initial level, and this was chosen as the $\mathrm{IC}_{50}$. Longer exposures resulted in additional toxicity to the cells. These results demonstrate that silver nanoparticles mediate a concentration and time dependent increase in toxicity. Silver nanoparticles had important anti angiogenic properties [23], so are attractive for study of their potential antitumor effects. The toxicity of nanosilver on oestoblast cancer cell lines results demonstrate a concentration-dependent toxicity with $3.42 \mu \mathrm{g} / \mathrm{ml}$ of $\mathrm{IC}_{50}$ suggest that the product is more toxic to cancerous cell comparing to other heavy metal ions [24]. Therefore our tissue culture derived silver nanoparticles of Citrullus colocynthis serve as antitumor

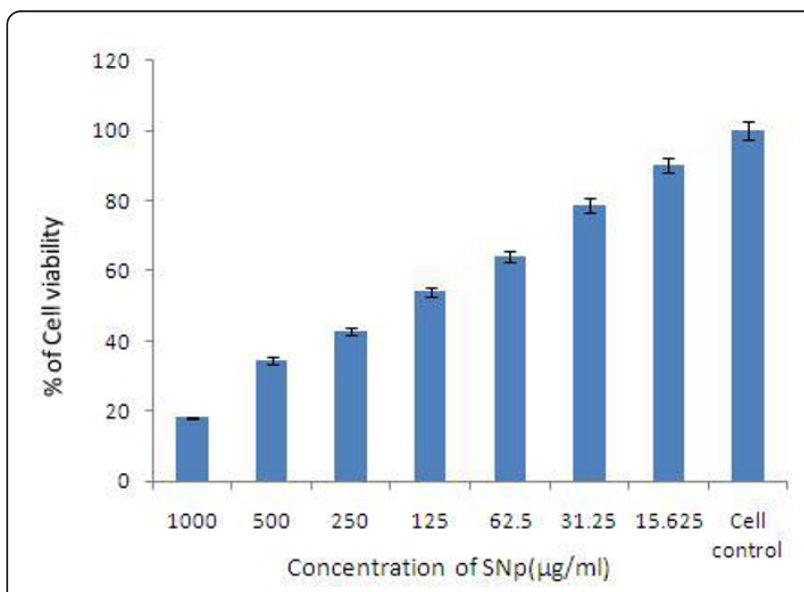

Figure $\mathbf{5}$ MTT assay. Cytotoxicity of different concentration (15.25 $-1000 \mu \mathrm{g} / \mathrm{ml}$ ) of silver nanoparticles measured by MTT assay on Hep2 cell line. agents by decreasing progressive development of tumor cells.

According to the levels of lactate dehydrogenase (LDH) released into the medium of control and synthesized silver nanoparticles treated $(20,40,60,80$ and 100 $\mu \mathrm{g} / \mathrm{ml}$ ) HEp2 cells are presented in Table 1. From this table, it was observed that LDH activities found to be significantly elevated after $48 \mathrm{~h}$ of exposure in the medium containing silver nanoparticles when compared to the control.

Also, the cellular metabolic activity affected by the silver nanoparticles, the possibility of apoptosis induction by the nanoparticles was assessed, especially at the $\mathrm{IC}_{50}$. Levels of caspase 3, a molecule which plays a key role in the apoptotic pathway of cells, were increased following the treatment with silver nanoparticles. The cell lysates obtained from HEp2 cells treated with silver nanoparticles at $500 \mathrm{nM}$ concentrations for six hours was used for this assay. Caspase 3 activation suggested that silver nanoparticles caused cell death through apoptosis, which was further supported by cellular DNA fragmentation. DNA ladders of the corresponding treated samples confirmed apoptosis (Figure 6) and showed that the silver nanoparticles treated HEp2 cells exhibited extensive double strand breaks, thereby yielding a ladder appearance (Lane 2), while the DNA of control HEp2 cells supplemented with $10 \%$ serum exhibited minimum breakage (Lane 1) (Figure 7).

However, when compared as a function of the $\mathrm{Ag}^{+}$ concentration, toxicity of AgNP appeared to be much higher than that of $\mathrm{AgNO}_{3}$ [25]. The cytotoxic effects of silver are the result of active physicochemical interaction of silver atoms with the functional groups of intracellular proteins, as well as with the nitrogen bases and phosphate groups in DNA [26]. Regular green tea and decaffeinated green tea exhibit dose-dependent inhibitory activity in (H1299 cell line) human lung carcinoma cell line. Also the apoptosis mechanism is induced in the presence of polyphenols concentrations were less [27].

This may be due to their inhibitory activities in several signaling cascades responsible for the development and pathogenesis of the disease which are as yet not understood. Taken together, our data suggest that silver nanoparticles can induce cytotoxic effects on HEp -2 cells, inhibiting tumor succession and thereby effectively controlling disease progression without toxicity to normal cells and these agents an effective alternative in tumor and angiogenesis-related diseases.

\section{Conclusion}

In conclusions, plant based sliver nanoparticles possess considerable anticancer effect compared with commercial nanosilver. The reduction of the metal ions through 
Table 1 Cell viability and LDH Leakage in control and SNp, treated HEp2 cells after 48 h of exposure

\begin{tabular}{cccc}
\hline Concentration $(\boldsymbol{\mu g} / \mathrm{ml})$ & Percentage of inhibition & $\begin{array}{c}\text { LDH activity } \\
(\mu \mathrm{mol} \text { of NADH/per well/min.) }\end{array}$ \\
\hline & Control & 0 & $0.10 \pm 0.004$ \\
DMSO $1 \%(\mathrm{v} / \mathrm{v})$ & 0 & $0.12 \pm 0.005$ \\
$20(\mu \mathrm{g} / \mathrm{ml})$ & 0 & $0.14 \pm 0.006^{*}$ \\
$40(\mu \mathrm{g} / \mathrm{ml})$ & $21.98 \pm 1.47^{*}$ & $0.20 \pm 0.01^{*}$ \\
$60(\mu \mathrm{g} / \mathrm{ml})$ & $50.14 \pm 1.24^{*}$ & $0.38 \pm 0.02^{*}$ \\
\hline $100(\mu \mathrm{g} / \mathrm{ml} / \mathrm{ml})$ & $67.60 \pm 1.42^{*}$ & $0.46 \pm 0.02^{*}$ \\
\hline
\end{tabular}

Each values represents mean + SD of 3 replicates $* P<0.001$ Vs Control

the callus extracts leading to the formation of silver nanoparticles of fairly well defined dimensions. Use of AgNPs should emerge as one of the novel approaches in cancer therapy and, when the molecular mechanism of targeting is better understood, the applications of AgNPs are likely to expand further [28].

\section{Materials and Methods}

\section{Plant material and preparation of the extract}

Fresh Citrullus colocynthis leaves were collected from the Southeast coast of Parangipettai (Tamil Nadu) India. The specimen was certified by Botanical Survey of India (BSI) Coimbatore, and documented in the Herbaria of C.A.S. in Marine Biology, Annamalai University, India, during 2010. The experimental chemicals were purchased from Sigma Chemicals (Mumbai).

\section{Sample preparation for synthesis of Silver Nanoparticles} One month old compact, hard greenish white callus derived from stem explants was used to obtain the callus extract in our lab [29]. The callus was washed twice with sterile distilled water to remove medium components before grinding. Approximate $20 \mathrm{~g}$ of callus was grinded in $100 \mathrm{ml}$ of sterile distilled water in mortar and pestle. The resulting extract was filtered through filter paper (What man No.1) and used for the

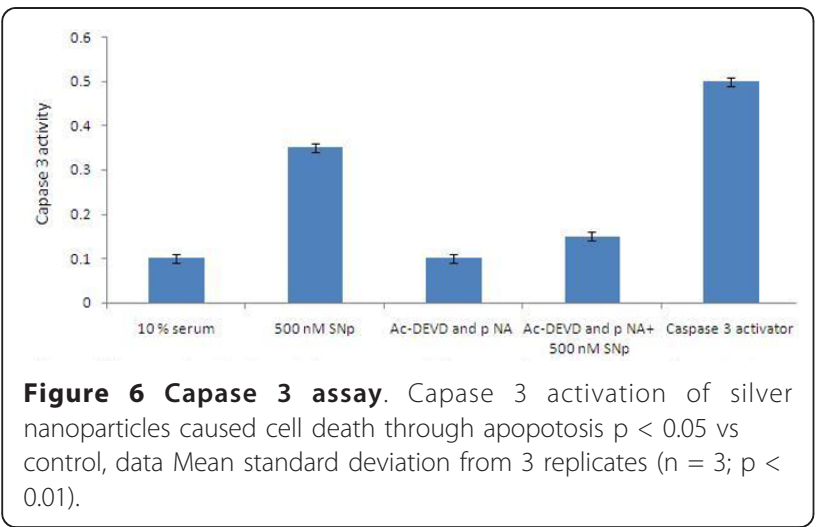

synthesis of silver nanoparticles. $10 \mathrm{ml}$ suspension of callus culture was added to $90 \mathrm{ml}$ aqueous solution of silver nitrate $(1 \mathrm{mM})$ solution separately

for reduction in to $\mathrm{Ag}+$ ions and incubated at room temperature $\left(35^{\circ} \mathrm{C}\right)$ for about 24 hours. The primary detection of synthesized silver nanoparticles was carried out in the reaction mixture by observing the colour change of the medium from greenish to dark brown. The silver nanoparticles were isolated and concentrated by repeated (4-5 times) centrifugation of the reaction mixture at $10,000 \mathrm{~g}$ for $10 \mathrm{~min}$. The supernatant was replaced by distilled each time and suspension stored as lyophilized powder for the optical measurements.

\section{Atomic Force Microscope}

Purified SNP in suspension was also characterized their morphology using a VEeco diNanoscope 3D AFM (Atomic Force Microscope). A small volume of sample was spread on a well-cleaned glass cover slip surface mounted on the AFM stub, and was dried with nitrogen flow at room temperature. Images were obtained in tapping mode using a silicon probe cantilever of $125 \mu \mathrm{m}$ length, resonance frequency $209-286 \mathrm{kHz}$, spring constant $20-80 \mathrm{~nm}^{-1}$ minimum of five images for each sample were obtained with AFM and analyzed to ensure reproducible results.

\section{Fourier Transform Infra Red Spectroscope}

To identify Silver nanoparticles associated biomolecules, the Fourier transform infra red spectra of washed and purified Silver nanoparticles powder were recorded on the Nicolet Avatar 660 FT-IR Spectroscopy (Nicolet, USA) using $\mathrm{KBr}$ pellets. To obtain good signal to noise ratio, 256 scans of Silver nanoparticles were taken in the range of $400-4000 \mathrm{~cm}-1$ and the resolution was kept as $4 \mathrm{~cm}^{-1}$

\section{Determination of Nanoparticles concentration}

Accurate determination of the size and concentration of nanoparticles is essential for biomedical application of 
with MEM medium with 2-10\% Fetal Calf Serum (FCS) and incubated at $37^{\circ} \mathrm{C}$ in a $5 \% \mathrm{CO}_{2}$ atmosphere. After $48 \mathrm{~h}$ incubation period, the attached cells were trypsinated for 3- 5 mints and centrifuged at 1, $400 \mathrm{rpm}$ for 5 mints. The cells counted and distributed in 24 well micro titer plates with 10,000 cells in each well and incubated $48 \mathrm{hrs}$ at $37^{\circ} \mathrm{C}$ in a $5 \% \mathrm{CO}_{2}$ atmosphere for the attachment of cells to bottom of the wells.

\section{Cell Treatment with silver nanoparticles}

The amount of different concentrations of stabilized silver nanoparticles was added to each well in duplicates. The different silver nanoparticles concentrations $(15,30$, $62,125,250,500,1000 \mu \mathrm{g} / \mathrm{ml}$ ) were inoculated in to grown cell $\left(1 \times 10^{4}\right.$ cells/well $)$ and the cell population was determined by optical microscopy at 24 and $48 \mathrm{hrs}$.

\section{MTT assay}

Cell viability was evaluated by MTT colorimetric technique [30]. $200 \mu \mathrm{l}$ of the yellow tetrazolium (MTT (3-(4, 5-dimethylthiazol-2)-2, 5 diphenyl tetrazolium bromide) without phenol red, are yellowish in color (Sigma) solution $(5 \mathrm{mg} / \mathrm{mL}$ in PBS) was added to each well. The plates were incubated for $3-4 \mathrm{~h}$ at $37^{\circ} \mathrm{C}$, for reduction of MTT by metabolically active cells, in part by the action of dehydrogenase enzymes, to generate reducing equivalents such as NADH and NADPH. The resulting intracellular purple formazan solubilized the MTT crystals by adding and quantified by spectrophotometric mean and then the supernatants were removed. For solubilization of MTT crystals, $100 \mu \mathrm{l}$ DMSO was added to the wells. The plates were placed on a shaker for 15 mints for complete solubilization of crystals and then the optical density of each well was determined. The quantity of formazan product was measured by the amount of 545 $\mathrm{nm}$ absorbance is directly proportional to the number of living cells in culture. The relative cell viability (\%) related to control wells containing cell culture medium without nanoparticles as a vechicle was calculated by $[\mathrm{A}]_{\text {test }} /[\mathrm{A}]_{\text {control }} \times 100$. Where $[\mathrm{A}]_{\text {test }}$ is the absorbance of the test sample and $[\mathrm{A}]_{\text {control }}$ is the absorbance of control sample

\section{Lactate Dehydrogenase (LDH) leakage assay}

Intracellular lactate dehydrogenase (LDH) leakage, a well known indicator of cell membrane integrity and cell viability was performed by the method of Borna et al., (2009) [31]. $100 \infty \mathrm{l}$ of silver nanoparticles was added to a $1 \mathrm{ml}$ cuvette containing $0.9 \mathrm{ml}$ of a reaction mixture to yield a final concentration of $1 \mathrm{mM}$ pyruvate, $0.15 \mathrm{mM}$ NADH and $10^{4} \mathrm{mM}$ disodium hydrogen phosphate. After mixing thoroughly, the absorbance of the solution was measured at $340 \mathrm{~nm}$ for 45 seconds. LDH activity was expressed as moles of NADH used per minute per well.

\section{Caspase 3 assay}

Caspase- 3 is an intracellular cysteine protease that exists as a proenzyme, becoming activated during the cascade 
of events associated with apoptosis. Caspase- 3 cleaves a variety of cellular molecules that contain the amino acid motif DEVD such as poly ADP-ribose polymerase (PARP), the $70 \mathrm{kD}$ protein of the U1-ribonucleoprotein and a subunit of the DNA dependent protein kinase [32]. The presence of caspase- 3 in cells of different lineages suggests that caspase- 3 is a key enzyme required for the execution of apoptosis [33]. The cells were lysed with the lysis buffer provided in the caspase 3 assay kit (Sigma, USA) and kept on ice for 15-20 minutes. The assay is based on the hydrolysis of the peptide substrate, AcDEVD-pNA, by caspase 3, resulting in the release of AcDEVD and $p$ nitroaniline (pNA) which absorbs light significantly at $450 \mathrm{~nm}$. Briefly, for $1 \mathrm{~mL}$ of the reaction mixture, $10 \mathrm{~mL}$ of the cell lysate from treated samples was added along with $980 \mathrm{~mL}$ of assay buffer, followed by addition of $10 \mathrm{~mL}$ of $20 \mathrm{mM}$ caspase 3 colorimetric substrate (Ac-DEVD pNA). The cell lysates of the SNp-treated Hep-2 cells were then incubated at $37^{\circ} \mathrm{C}$ with the caspase 3 substrate for two hours and the absorbance was read at $450 \mathrm{~nm}$ in a double-beam UV- spectrophotometer (Shimadzu, Japan). The assay was also performed with noninduced cells and in the presence of caspase 3 inhibitor for a comparative analysis.

\section{DNA fragmentation assay}

DNA fragmentation has long been used to distinguish apoptosis from necrosis, and is among the most reliable methods for detection of apoptotic cells. When DNA strands are cleaved or nicked by nucleases, 3'-hydroxyl ends are exposed. $1 \times 10^{6}$ cells were lysed in $250 \mu \mathrm{L}$ cell lysis buffer containing $50 \mathrm{mM}$ Tris $\mathrm{HCl}, \mathrm{pH} 8.0,10 \mathrm{mM}$ ethylenediaminetetraacetic acid, $0.1 \mathrm{M} \mathrm{NaCl}$, and $0.5 \%$ sodium dodecyl sulfate. The lysate was incubated with $0.5 \mathrm{mg} / \mathrm{mL}$ RNase A at $37^{\circ} \mathrm{C}$ for one hour, and then with $0.2 \mathrm{mg} / \mathrm{mL}$ proteinase $\mathrm{K}$ at $50^{\circ} \mathrm{C}$ overnight. Phenol extraction of this mixture was carried out, and DNA in the aqueous phase was precipitated by $25 \mu \mathrm{L}(1 / 10$ volume) of $7.5 \mathrm{M}$ ammonium acetate and $250 \mu \mathrm{L}(1 / 1$ volume) isopropanol. DNA electrophoresis was performed in a $1 \%$ agarose gel containing $1 \mu \mathrm{g} / \mathrm{mL}$ ethidium bromide at $70 \mathrm{~V}$, and the DNA fragments were visualized by exposing the gel to ultraviolet light, followed by photography.

\section{Statistical analysis}

All experiments were done in duplicate and then values were expressed as mean \pm standard deviation (SD). Statistical significance $(5 \%)$ was evaluated by one-way analysis of variance (ANOVA) followed by Student's t-test $(\mathrm{p}<0.05$, SPSS 11 version).

\section{Acknowledgements}

The authors are gratefully acknowledge to the Director \& Dean, Faculty of Marine Sciences, Annamalai University, Parangipettai, Tamil Nadu, India for providing all support during the study period.

\section{Authors' contributions}

All authors read and approved the final manuscript.

KS and SG developed the concept and designed experiments. TR was research guide of this experimental study. SG and KS performed plant collection, micropropagation, nanoparticles synthesis, characterization and cell line studies. TR \& TB provided chemicals, Instrumental studies and advised on experimental part.

\section{Competing interests}

A patent application will be filed with the content of this article, through the Annamalai University. The authors declare that they have no competing interests.

Received: 12 May 2011 Accepted: 26 September 2011

Published: 26 September 2011

\section{References}

1. Gurudeeban S, Rajamanickam E, Ramanathan T, Satyavani K: Antimicrobial activity of Citrullus colocynthis in Gulf of Mannar. International Journal of Current Research 2010, 2:78-81.

2. Gurudeeban S, Ramanathan T: Antidiabetic effect of Citrullus colocynthis in alloxon-induced diabetic rats. Inventi Rapid: Ethno pharmacology 2010, 1:112.

3. Rajamanickam E, Gurudeeban S, Ramanathan T, Satyavani K: Evaluation of anti inflammatory activity of Citrullus colocynthis. International Journal of Current Research 2010, 2:67-69.

4. Gurudeeban S, Ramanathan T, Satyavani K: Antioxidant and radical scavenging activity of Citrullus colocynthis. Inventi Rapid: Nutracuticlas 2010, 1:38.

5. Jhan W: Chemical aspects of the use of gold clusters in structural biology. J Struct Biology 1999, 127:106.

6. Murphy CJ: Sustainability as an emerging design criterion in nanoparticle synthesis and applications. J Mater Chem 2008, 18:2173-2176.

7. Schultz S, Smith DR, Mock JJ, Schultz DA: Single-target molecule detection with non bleaching multicolor optical immunolabels. Proceedings of the National Academy of Sciences 2000, 97:996-1001.

8. Nair B, Pradeep T: Coalescence of nanoclusters and formation of submicron crystallites assisted by Lactobacillus strains. Cryst Growth Des 2002, 2:293-298.

9. Willner I, Baron R, Willner B: Growing metal nanoparticles by enzymes. Adv Mater 2006, 18:1109-1120.

10. Chandran SP, Chaudhary M, Pasricha R, Ahmed A, Sastry M: Synthesis of gold nanotriangles and silver nanoparticles using Aloe vera plant extract. Biotechnology Prog 2006, 22:577.

11. Sahoo SK, Ma W, Labhasetwar V: Efficacy of transferring-conjugated paclitaxel-loaded nanoparticles in a murine model of prostate cancer. Int J Cancer 2004, 112:335.

12. Vidyanathan R, Llishwaralal K, Gopalram S, Gurunathan S: Nanosilver-The burgeoning therapeutic molecule and its green synthesis. Biotechnol Adv 2009, 27:924.

13. Satyavani K, Ramanathan T, Gurudeeban S: Green Synthesis of Silver Nanoparticles by using stem derived callus extract of Bitter apple (Citrullus colocynthis). Digest Journal of Nanomaterials and Biostructures 2011, 6:1019-1024.

14. Satyavani K, Ramanathan T, Gurudeeban S: Plant Mediated Synthesis of Biomedical Silver Nanoparticles by Using Leaf Extract of Citrullus colocynthis. Research Journal of Nanoscience and Nanotechnology 2011, 1(2):95-101.

15. Narmata Mude, Avinash Ingle, Aniket Gade, Mahendra Rai: Synthesis of silver nanoparticles using callus extract of Carica papaya - A First Report. J Plant Biochemistry and Biotechnology 2009, 18:83-86.

16. Li S, Shen Y, Xie A, Yu X, Qiu L, Zhang Q: Green synthesis of silver nanoparticles using Capsicum annuum L. extract. Green Chem 2007, 9:852-858

17. Song JY, Kim BS: Rapid biological synthesis of silver nanoparticles using plant leaf extracts. Bioprocess Biosyst Eng 2009, 32:79-84.

18. Songa JY, Janga HK, Kim BS: Biological synthesis of gold nanoparticles using Magnolia kobus and Diopyros kaki leaf extracts. Process Biochem 2009, 44:1133-1138. 
19. Huang Xiaohua, Prashant Kain, Ivan HEl-Sayed, Mostafa AEl-Sayed: Focus: Nanoparticles for Cancer Diagnosis \& Therapeutics - Review.

Nanomedicine 2007, , 5: 681-693.

20. Shivshankar S, Ahmad A, Sastry M: Geranium leaf assisted biosynthesis of silver nanoparticles. Biotechnol Prog 2003, 19:1627-1631.

21. Krishnan R, Maru GB: Isolation and analysis of polymeric polyphenol fractions from black tea. Food Chem 2006, 94:331-340

22. O'Coinceanainn MO, Astill C, Schumm S: Potentiometric FTIR and NMR studies of the complexation of metals with theaflavin. Dalton Trans 2003, 5:801-807.

23. Gurunathan S, Lee K, Kalimuthu K, Sheikpranbabu S, Vaidyanathan R, Eom SH: Anti angiogenic properties of silver nanoparticles. Biomaterials 2009, 30:6341.

24. Moaddab S, Hammed Ahari, Delavar Shahbazzadeh, Abbas Ali Motallebi, Amir Ali Anvar, Jaffar Rahman-Nya, Mohamaad Reza Shokrgozar: Toxicity Study of Nanosilver (Nanocid) on Osteoblast Cancer Cell Line. Int Nano Lett 2011, 1:11-16.

25. Navarro Enrique, Piccapietra Flavio, Wagner Bettina, Marconi Fabio, Kaegei Ralf, Odzak Niksa, Sigg Laura, Behra Renata: Toxicity of Silver Nanoparticles to Chlamydomonas reinhardtii. Environmental Science Technol 2008, 42:8959-8964.

26. Blagoi YP, Sorokin VA: Metal ion interaction with DNA. Experimental results and theoretical models. Studia Biophysica 1991, 128:81-8.

27. Guang-Yu Yang, Jie Liao, Kyounghyun Kim, Edward JYurkow, Chung SYang: Inhibition of growth and induction of apoptosis in human cancer cell lines by tea polyphenols. Carcinogenesis 1998, 19:611-616.

28. Vaidyanathan R, Kalishwaralal K, Gopalram S, Gurunathan S: Nanosilver the burgeoning therapeutic molecule and its green synthesis. Biotechnol Adv 2009, 27:924-937.

29. Satyavani K, Ramanathan T, Gurudeeban S: Effect of Plant Growth Regulators on Callus Induction and Plantlet Regeneration of Bitter Apple (Citrullus colocynthis) from Stem Explants. Asian J Biotechnol 2011, 3:246-253.

30. Khlebtsov NG: Determination of size and concentration of gold nanoparticles from extinction spectra. Anal Chem 2008, 80:6620.

31. Marquis $B J$, Love $S A$, Braun $K L$, Haynes $C L$ : Analytical methods to assess nanoparticles toxicity. Analyst 2009, 134:425.

32. Mosmann T: Rapid colorimetric assay for cellular growth and survival: application to proliferation and cytotoxicity assays. J Immunol Methods 1983, 65:55.

33. Borna S, Abdollahi A, Mirzaei F: Predictive value of mid-trimester amniotic fluid high-sensitive C-reactive protein, ferritin, and lactate dehydrogenase for fetal growth restriction. Indian J Pathol Microbiol 2009, 52(4):498-500.

doi:10.1186/1477-3155-9-43

Cite this article as: $\mathrm{K}$ et al.: Biomedical potential of silver nanoparticles synthesized from calli cells of Citrullus colocynthis (L.) Schrad. Journal of Nanobiotechnology 2011 9:43.

\section{Submit your next manuscript to BioMed Central and take full advantage of:}

- Convenient online submission

- Thorough peer review

- No space constraints or color figure charges

- Immediate publication on acceptance

- Inclusion in PubMed, CAS, Scopus and Google Scholar

- Research which is freely available for redistribution

Submit your manuscript at www.biomedcentral.com/submit 